\title{
Does the Mauritian Constitution protect the right to privacy? An insight from Madhewoo $v$ The State of Mauritius
}

\section{Roopanand Mahadew}

Senior Lecturer, Department of Law, Faculty of Law and Management, University of Mauritius

\begin{abstract}
Summary
This article analyses the substantive content of the right to privacy in Mauritius pursuant to the Supreme Court's decision regarding proposed biometric identity cards. It provides for an overview of this critical decision from both a factual and legal point of view before assessing the way in which the Supreme Court has evaluated the limitation of rights to justify a restriction on the right to privacy in Mauritius. The article focuses on statements made by the judges from which inferences may be made on the content of the right to privacy and the degree of judicial activism shown in the case. The decision indicates that the Constitution of Mauritius only provides for a limited and incomplete right to privacy - of the home, body and property. This position is not in line with the international obligations of Mauritius under the African Charter on Human and Peoples' Rights and the International Covenant on Civil and Political Rights, in terms of which the right to privacy should be interpreted more broadly. While the Supreme Court has carried out the exercise of the limitation of rights correctly, its approach in the interpretation of the right to privacy has been restrictive and not generous and purposive. The judicial restraint shown by the apex court is of concern for human rights law interpretation in Mauritius.
\end{abstract}

Key words: Mauritius; right to privacy; Supreme Court; Constitution

* LLB (Mauritius) LLM (Human Rights and Democratisation in Africa) (Pretoria); r.mahadew@uom.ac.mu 


\section{Introduction}

As the Republic of Mauritius prepares to celebrate the 50th anniversary of its Constitution in March 2018, it is inevitable that debates and discussions around the Constitution are frequent. The Constitution has accompanied Mauritius on its journey from an underdeveloped state to an emerging economy. The Constitution's restricted Bill of Rights and the potential for improvement to ensure a better future for the country attract the attention of many citizens and international observers. Indeed, the Mauritian Constitution has proved to be decisive in many spheres of the political, social, cultural and economic lives of Mauritians. For instance, the 'best loser' system embodied in one of its schedules has played a major role in ensuring the political representation of racial minorities in the National Assembly in Mauritius. ${ }^{1}$ It has provided a constitutional guarantee for Mauritius to be a democratic state based on the rule of law, and the principle of separation of powers has been constitutionally entrenched. ${ }^{2}$ At the same time, the Constitution has retained an unchanged Bill of Rights which provides only for civil and political rights.

The Bill of Rights again came under the spotlight with the introduction in 2013 of the new smart national identity card (ID card) which incorporates a citizen's fingerprints and biometric information related to his or her external characteristics. Questions were raised on numerous human rights, and in particular on the right to privacy, considered later in the article. There was a constant fear that an ID card which contains so much personal information would prove to be too intrusive and in violation of one's right to privacy. Mr Maharajah Madhewoo, a Mauritian citizen, challenged the constitutionality of the law allowing the introduction of the smart ID card. As a result, the Supreme Court of Mauritius had the opportunity to once again interpret the Constitution and to prove whether it is a living document or not.

The article aims to critically analyse the case of Madhewoo $v$ The State of Mauritius (Madhewoo case) ${ }^{3}$ and its implications for the rights to privacy of Mauritians. It contributes towards a knowledge of the interpretation of the Bill of Rights in Mauritius and the overarching corpus of human rights in Mauritius. The introduction precedes the next section that provides for a general overview of the right to privacy in order to highlight its importance as has been done by

1 R Mahadew 'The best loser system in Mauritius: An essential electoral tool for representing political minorities' in E Durojaye et al (eds) Constitutional building in Africa (2015) 160.

2 Ahnee $v$ Director of Public Prosecutions [1999] 2 AC 294, 302-303; The State $v$ Khoyratty [2006] UKPC 13.

3 Madhewoo $v$ The State of Mauritius \& Another 2015 SCJ 177 ionnews.mu/wpcontent/uploads/2015/.../Biometric-ID-Card_Madhewoo-vs-State.pdf (accessed 15 June 2018). 
global and regional human rights systems. This is followed by a summary of the facts and the legal reasoning of the aforementioned case. A few words are reserved for the decision of the Judicial Committee of the Privy Council to which the case of Madhewoo went on appeal from the Mauritian Supreme Court in 2016. In the end, the implications of the Madhewoo case are analysed, providing the platform for a conclusion and some recommendations.

\section{Right to privacy as interpreted by the global human rights architecture}

\subsection{What is the right to privacy?}

Privacy is regarded as a fundamental right which is essential for the autonomy and human dignity of individuals. It is a critical right since other human rights are founded on the right to privacy or its derivatives, such as the right to a private life or secrecy of the home. ${ }^{4}$ It acts as a guarantee against unwarranted interference in the lives of individuals by permitting the setting up of boundaries and creating barriers. It provides the foundation based for boundaries to be established to restrict who has access to one's place, things and body, as well as one's communications and information. ${ }^{5}$ The right to privacy also allows individuals to assert their rights, especially in the face of imbalances in power. ${ }^{6}$ It is an essential means by which individuals protect themselves and society in general from the arbitrary and unjustified use of power.

The right to respect privacy reflects the liberal concept of the individual as independent and self-governing, who has the freedom to enjoy and exercise all his or her rights without interfering with the rights of others. It implies that any state interference with a right that only concerns the individual - such as the right to choose a marriage partner or the number of children to have as a couple - amounts to a violation of privacy. ${ }^{7}$ The right to privacy entails the right to protect an individual's identity, intimacy, gender, name, honour, dignity, sexual orientation, feelings and appearance. ${ }^{8}$ It is a right that extends to the family, home and correspondence. 'Family' has been interpreted as relating to blood ties, economic ties, acquired by

4 Privacy International 'What is privacy?' https://www.privacyinternational.org/ node/54 (accessed 2 January 2017).

5 D Solove 'Conceptualising privacy' (2002) 90 California Law Review 1092.

6 K Hurwitz K 'Imbalances in power' (2003) https://www.humanrightsfirst.org/wpcontent/uploads/pdf/powers.pdf (accessed 2 January 2017).

7 J Pull 'Questioning the fundamental right to marry' (2006) Yale Law School Legal Scholarship Repository 41 http://digitalcommons.law.yale.edu/cgi/viewcontent.cgi? article $=1026 \&$ context=student_papers (accessed 21 June 2018).

8 Icelandic Human Rights Centre 'The right to privacy and family life' http:// www.humanrights.is/en/human-rights-education-project/human-rights-conceptsideas-and-fora/substantive-human-rights/the-right-to-privacy-and-family-life (accessed 2 January 2017). 
adoption or marriage. 9 Privacy of the home includes a place of business, and privacy of correspondence includes protection from secret surveillance and censorship of the correspondence of prisoners. ${ }^{10}$ However, the right to privacy is not an absolute right is as it can be limited under specific conditions, provided that such intervention by the state is not unlawful or arbitrary. ${ }^{11}$

\subsection{International standards protecting the right to privacy}

The right to privacy is enshrined in both the Universal Declaration of Human Rights (Universal Declaration) and the International Covenant on Civil and Political Rights (ICCPR) in the following terms, that '[n]o one shall be subjected to arbitrary interference with his privacy, family, home or correspondence, nor to attacks upon his honour and reputation' and that '[e]veryone has the right to protection of the law against such interference or attacks' ${ }^{12}$ Similar wording has been used to provide for the same right by the Convention on Migrant Workers in article 14 to protect migrant workers from interference in their private lives and families. The Convention on the Rights of the Child (CRC) and the Convention on the Rights of Persons with Disabilities (CRPD) guarantee privacy to children and persons living with disabilities in articles 16 and 22 respectively.

The European Convention on Human Rights (European Convention) focuses specifically on possible limitations to the right to privacy. Article 8 provides that the authority may not interfere with this right except in accordance with the law and when it is necessary in the interests of a democratic society; in the interests of national security, public safety or economic well-being of the country; for the prevention of disorder or crime; for the protection of health and morals; or for the protection of the rights and freedoms of others. ${ }^{13}$ The American Convention on Human Rights provides for the right to privacy, honour and dignity in article 11 and prohibits arbitrary interference with these rights. In contrast, the African Charter on Human and Peoples' Rights (African Charter) does not explicitly establish the right to privacy. However, article 18 emphasises the state's duty to protect the family. In direct or indirect ways, the right to privacy is provided for in numerous international instruments as well as in various constitutions around the world. ${ }^{14}$

9 Icelandic Human Rights Centre (n 8 above).

10 See Liberty 'Article 8 Right to a private life and family life' https://www.libertyhuman-rights.org.uk/human-rights/what-are-human-rights/human-rights-act/ article-8-right-private-and-family-life (accessed 2 January 2017).

11 K Himma 'Privacy versus security: Why privacy is not an absolute value or right' (2007) 44 San Diego Law Review 857.

12 Art 12 Universal Declaration; art 17 ICCPR.

13 R Pati 'Rights and their limits: The constitution for Europe in international and comparative perspective' (2005) 23 Berkeley Journal of International Law 268.

14 Art 14 United Nations Convention on Migrant Workers; art 10 African Children's Charter; art 16 CRC; art 4 African Union Principles on Freedom of Expression; art 5 
The right to protection of personal data is an essential element of the right to privacy. The right to data protection normally can be inferred from the general and overarching right to privacy. However, because of its utmost importance in a technologically-advanced world, several international and regional instruments stipulate the specific right to protection of personal data. These include the Guidelines on the Protection of Privacy and Trans-Border Flows of Personal Data of the Organisation for Economic Co-operation and Development (OECD); the Council of Europe Convention 108 for the Protection of Individuals with Regard to Automatic Processing of Personal Data; the Asia-Pacific Economic Co-operation Privacy Framework 2004; and the Economic Community of West African States (ECOWAS) Supplementary Act on Data Protection of 2010. ${ }^{15}$

\subsection{Interpretation of the right to privacy by judicial and quasi- judicial bodies}

The United Nations (UN) Human Rights Committee, the body responsible for monitoring the implementation of the ICCPR, has been active in interpreting the right to privacy. In Coeriel and Aurik $v$ The Netherlands ${ }^{16}$ it found that the right to privacy had been violated when individuals were prohibited from changing their names for religious reasons. In Toonen $v$ Australia, ${ }^{17}$ a blanket prohibition on homosexuality was held to be in violation of the right to privacy. Furthermore, the state's action of dispossessing indigenous persons of their ancestral burial ground was held to be violating privacy in the case of Hopu and Bessert $v$ France. ${ }^{18}$ With regard to control and censorship of correspondence, the Human Rights Committee adjudicated in the case of Estrella $v$ Uruguay $^{19}$ that excessive control over and actions of censoring the correspondence of prisoners may amount to a violation of the right to privacy. In contrast, in the case of Van Hulst $v$ The Netherlands ${ }^{20}$ the Committee held that where taped conversations between a complainant and the lawyer were admitted as evidence in criminal proceedings, this did not amount to a violation of the right to privacy.

American Declaration of the Rights and Duties of Man; art 21 Arab Charter on Human Rights; art 21 ASEAN Human Rights Declaration.

15 See $P$ de Hert 'The right to protection of personal data: Incapable of autonomous standing in the basic EU constituting documents?' (2015) 31 Utrecht Journal of International and European Law 4.

16 Communication 453/1991 UNHR Committee UN Doc CCPR/C/52/D/453/1991 (1994) 9 December 1991.

17 Communication 14/1991 UNHR Committee UN Doc CCPR/C/50/D/488/1992 (1994) 4 April 1991.

18 Francis Hopu and Tepoaitu Bessert v France Communication 549/1993 UNHR Committee UN Doc CCPR/60/D/549 1 August 1997.

19 Miguel Angel Estrella v Uruguay Communication 74/1980 UNHR Committee UN Doc CCPR/C/OP/2 (1990) 29 March 1983.

20 Antonius Cornelis van Hulst $v$ The Netherlands Communication 903/1999 UNHR Committee UN Doc CCPR/C/82/D/903/1999 (2004) 5 November 2004. 
The decisions of the European Court of Human Rights (European Court) on the issue of privacy are diverse, which is testimony of the fact that the right to privacy is subject to interpretation and relatively wide-ranging and expansive in nature. For instance, in Huvig $v$ France, $^{21}$ the European Court held that the tapping of telephone conversations 'not in accordance with the law' created a violation of privacy. The search of journalists' homes and the seizure of their documents were held to be in contravention of privacy as decided in the case of Ernst \& Others $v$ Belgium. ${ }^{22}$ The right to privacy has also been used in the context of abortion in the case of Tysiac $v$ Poland. ${ }^{23}$ The European Court held that the state's refusal to perform a therapeutic abortion despite a serious risk of deterioration in the mother's eyesight amounted to a transgression of the right to privacy.

An overview of the judicial and quasi-judicial bodies of the world reveals that the right to privacy is crucial. This right is so important that in some cases, despite not being clearly or directly stipulated by the law - in international human rights treaties or domestic constitutions - courts have played an essential role in adjudicating that the right to privacy does exist in the formulation of other concepts, such as liberty or freedom or the right to life, by using the implied rights theory of interpretation. The Constitution of the United States of America is relevant here. The US Constitution does not expressly provide for the right to privacy. The question whether the US Constitution confers protection of privacy in ways not explicitly mentioned in the Bill of Rights has always been a controversial matter. ${ }^{24}$ Robert Bork J decided that no general right to privacy existed in the case of Dronenburg $v$ Zech. ${ }^{25}$ However, in the case of Lawrence $v$ Texas $^{26}$ the US Supreme Court reaffirmed the Constitution's protection of privacy, despite it not being explicitly provided for in the Constitution, in the following terms: ${ }^{27}$

These matters, involving the most intimate and personal choices a person may make in a lifetime, choices central to personal dignity and autonomy, are central to the liberty protected by the Fourteenth Amendment. At the heart of liberty is the right to define one's own concept of existence, of meaning, of the universe, and of the mystery of human life ... The petitioners are entitled to respect for their private lives. The state cannot demean their existence or control their destiny by making their private sexual conduct a crime. Their right to liberty under the Due Process Clause gives them the full right to engage in their conduct without intervention of

21 (1990) 12 EHRR 528.

22 (2003) 39 EHRR 35.

23 (2007) 45 EHRR 42.

24 See Exploring Constitutional Conflicts 'Does the Constitution protect the right to privacy?' http://law2.umkc.edu/faculty/projects/ftrials/conlaw/rightofprivacy.html (accessed 6 January 2017).

25741 F.2d 1388 (DC Cir 17 August 1984).

26539 US 558 (2003) (Texas).

27 See C Dailard 'What Lawrence $v$ Texas says about the history and future of reproductive rights?' (2003) 31 Fordham Urban Law Journal 717. 
the government. 'It is a promise of the Constitution that there is a realm of personal liberty which the government may not enter.'

It is evident that the US Supreme Court has not shied away from interpreting the right to privacy from broader concepts of the US Constitution such as liberty and dignity. It moved from a position where a blatant 'no right to privacy is provided' to rules of interpretation that can be used to protect the right to privacy. Such a stand is in contrast to the decision of the Supreme Court of Mauritius in the Madhewoo case, where the Court held that '[a]s opposed to those countries where the right to privacy or the respect for one's private life is constitutionally entrenched, in Mauritius the right to privacy is not provided for in the Constitution'. ${ }^{28}$ The following section of the article focuses on the Madhewoo case's facts and the decision, analysing the implications of the aforementioned statement by the Supreme Court. What are the implications of the deliberation that the right to privacy is not provided for in the Constitution? An attempt is made to shed light on this important section.

\section{Overview of the Madhewoo case}

According to the National Identity Card Act 1985 (1985 Act), all Mauritian citizens are legally obliged to carry an identity card bearing their name, picture and signature. In 2013 the former government (which changed after the 2014 general elections) proposed the introduction of a new smart identity card, incorporating an individual's fingerprints and other biometric information related to their external traits and characteristics. An amendment of the 1985 Act was required for the materialisation of the project. The National Identity Card (Miscellaneous Provisions) Act 2013 (2013 Act) was enacted. The project met with significant opposition and criticism from various sections of Mauritian society. ${ }^{29} \mathrm{Mr}$ Maharajah Madhewoo, a Mauritian citizen, challenged the constitutionality of the 2013 Act as the legislative vehicle for the new smart ID project. He sought redress under section 17 of the Constitution of Mauritius (Constitution) allowing citizens to apply to the Supreme Court in cases of violations of the provisions of sections 3 to 16 of the Bill of Rights.

After the amendment, the 1985 Act stipulates in section 3 that the Registrar of Civil Status shall keep a register, electronic or otherwise, in which a citizen's particulars are recorded. Furthermore, section 3(2) enumerates these particulars as follows: sex, names and 'such

28 Madhewoo case (n 3 above) 15.

29 D Battu 'The fight against biometric ID card in Mauritius' http://www.smartwebzine.com/en/la-lutte-contre-la-carte-didentite-biometrique-a-lile-maurice-68 02 (accessed 6 January 2017); D Lallah 'The slippery national identity card' Le Mauricien 14 October 2015 http://www.lemauricien.com/article/slippery-nationalidentity-card (accessed 6 January 2017). 
reasonable or necessary information as may be prescribed regarding the identity of the person'. The prescribed particulars in turn are provided for by the National Identity Card (Particulars in Register) Regulations 2013 (2013 Regulations) as being fingerprints and encoded minutiae of fingerprints. Section 4(2)(c) of the 1985 Act provides that every citizen within six months of attaining the age of 18 must apply for an identity card and must 'allow his fingerprints, and other biometric information about himself, to be taken and recorded'. In addition, the ID card containing biometric information of the individual must be produced by him upon request in (1) reasonable circumstances and for the purpose of ascertaining his identity; and (2) where the requestor is empowered by law to ascertain his identity. ${ }^{30}$ The fact that the laws on the new smart ID card require that fingerprints and other biometric information should be compulsorily given while applying for an ID card and that this biometric information would then be stored in a register by the Registrar of Civil Status was challenged in the Supreme Court as contravening various human rights, as considered below.

\subsection{Alleged breach of the right to life - Section 4 of the Constitution}

Counsel for the plaintiff contended that the right to life subsumed the right to privacy. He based this on the famous Indian case - the Aadhaar Scheme - whereby the applicants were compelled to give iris and fingerprints as biometric information to be used in the Aadhaar cards. The Supreme Court of India adjudicated that extracting such biometric information from an applicant infringed their right to privacy which is part of their right to life, as provided for by section 21 of the Indian Constitution. ${ }^{31}$

The Supreme Court of Mauritius rejected this contention on the basis that the wording of the Mauritian Constitution differs from that of the Indian Constitution with respect to the right to life. In a rather restrictive approach, the Mauritian Supreme Court held that life was protected in section 4 in contradiction to death. The Court further added that the circumstances under which the right to life may be infringed would be in relation to a person's death as a result of force that is reasonably justified for certain purposes. Therefore, the Court interpreted the right to life in a very restrictive manner as being a right dealing with life and death in the literal sense. What is required to live that life - dignity, liberty and privacy - has not been deemed to feature in section 4 . The Court, therefore, held that 'the law for the implementation of the new biometric card and for the collection and

30 Sec 7 of the 1985 Act.

31 See Binoy Visman v Union of India No 247 of 2017 https://indiankanoon.org/doc/ 51782092/ (accessed 21 June 2018). 
storage of personal biometric data does not constitute a breach of the right to life protected by section 4 of the Constitution'. ${ }^{32}$

\subsection{Alleged breach of the right to liberty - Section 5 of the Constitution}

The plaintiff further averred that the right to liberty, protected by section 5 of the Constitution, was infringed in the following terms:

The unilateral decision of Defendants of imposing a legal obligation upon him to submit his fingerprints and this, without his consent and further the collection, processing and/or retention of plaintiff's personal biometric information including his fingerprints constitutes a serious interference by Defendants and/or their agents and/or their employees with plaintiff's basic fundamental constitutional rights amongst the right to liberty and the right to protection of private life.

The plaintiff added that 'the blanket power of collection and the indefinite storage of personal biometric data, including fingerprints, on the biometric identity card of citizens, including plaintiff, are in breach of section 5 of the Constitution'. ${ }^{33}$

The Supreme Court examined section 5 of the Constitution and concluded that it only provided for the protection of physical liberty. Apparently, therefore, 'non-physical' liberty was not guaranteed by the supreme law of the land, if one follows the reasoning of the Court. The Court came to this conclusion by referring to the series of circumstances listed in sections $5(\mathrm{a})$ to $(\mathrm{k})$, according to which the deprivation of liberty is legally allowed. According to the Court, since the exceptions to the right to liberty - for instance, imprisonment after having been found guilty of a criminal offence - are physical in nature, implying that the 'protection which is afforded under section 5 is essentially in respect of the deprivation of the physical liberty of that person'. ${ }^{34}$ In other words, the exceptions define the nature of the principle right - a rather disturbing proposition.

The Court held that only persons authorised by section 7 of the 1985 Act could ask any individual to produce his ID card. Such a request, according to the Court, did not amount to a deprivation of the physical liberty of the person. The Court added: 35

The legal obligation created under section 4(2)(c) of the National Identity Card Act for a person to allow his fingerprints to be taken, and the provision under the Data Protection Act for the collection, retention and storage of personal data cannot be said to amount to an actual physical deprivation of personal liberty in breach of section 5 of the Constitution.

32 Madhewoo case (n 3 above) 7.

33 Madhewoo 8.

34 Madhewoo 9.

35 As above. 


\subsection{Alleged breaches of constitutional provisions related to privacy}

The right to privacy was the main human right on the basis of which the constitutionality of the new smart ID card project was being challenged. The plaintiff averred that sections 3 and 9 of the Constitution had been infringed by the extraction of minutiae from the fingerprints of citizens. The Court explained that by analysing the precise words of section 3, it was clear that the protection did not extend to the physical privacy of the person. It added that section 3 did not contain words or terms which confer a right to privacy of the person and which may encompass any protection against taking the fingerprints of a person. ${ }^{36}$ According to the Court, section 3 only appeared to confer protection on the privacy of a person's home and property. The Court relied on the Privy Council decision of Matadeen $v$ Pointu, ${ }^{37}$ where it was upheld that section 3 or the subsequent sections of the Constitution could not be interpreted as creating rights which they do not contain. ${ }^{38}$ The Court concluded that section 3, interpreted in light of its natural and ordinary meaning, did not confer any right of privacy to the person and, in the present case, would not afford constitutional protection against the taking of fingerprints as provided for under the 1985 Act.

The Court also addressed the argument put forward by the defendant as a response to the plaintiff's comparison of sections 3 and 9 of the Constitution with article 8 of the European Convention. The Court was of the view that these two legal provisions were not comparable as article 8 of the European Convention explicitly provides for the right to private life. It considered the various cases from the European Court of Human Rights on article 8 cited by the plaintiff to support his case, and held that they did not find application in view of the difference in the wording of that article when compared to section 9 of the Mauritian Constitution.

Addressing the issue of an infringement of sections 3 and 9 by the new smart ID card, the Court reiterated that constitutions were formulated in different terms and should each be read within its own particular context and framework. ${ }^{39}$ This statement came as a caution to the approach of comparing seemingly similar provisions in the Mauritian Constitution to that of the American and Indian Constitutions. It concluded that the provisions on privacy-related rights in the Mauritian Constitution did not bear a close resemblance to either the provisions of other cited constitutions or the European

36 Madhewoo (n 3 above) 17.

$371998 \mathrm{MR}$.

38 Matadeen $v$ Pointu (n 37 above) 172. 'Their Lordships would not wish in any way to detract from this statement of principle but it cannot mean that either section 3 or the later sections can be construed as creating rights which they do not contain.'

39 Union of Campement Sites Owners \& Others $v$ The Government of Mauritius 1984 MR 100. 
Convention. The Court pronounced that only article 22 of the Civil Code provided for a right to the protection of private life, and this did not have the status of a constitutional right. Therefore, at this point of the judgment it was made very clear by the judges that there was no constitutional right to privacy in Mauritius.

The Court subsequently focused specifically on section 9 of the Constitution, which states that '[e]xcept with his own consent, no person shall be subjected to the search of his person or his property or the entry by others on his premises'. The judges stated: ${ }^{40}$

Every adult citizen of Mauritius is bound to apply for a national identity card and is mandatorily required, under section 4(2) of the Act, 'to allow his fingerprints, and other biometric information about himself to be taken and recorded'.

In other words, a citizen is under the obligation to allow his fingerprints to be taken and stored, and the non-observance of this provision would amount to a criminal sanction provided for in section 9 of the 1985 Act, thus highlighting the coercive nature of the obligation.

The Court ultimately raised the essential question of whether

in view of the highly personal and private nature of fingerprints which contain sensitive personal information about an individual, the coercive act of taking his fingerprints would tantamount to a breach of the protection of his Constitutional right to privacy within the ambit of Section 9(1) of the Constitution. ${ }^{41}$

Put differently, the question was whether the coercive act of taking someone's fingerprints against his will would amount to him being 'subjected to the search of his person' as provided for in section 9.

The Court stated in the decision that a written constitution should not be construed as an Act of Parliament, but rather as a covenant to which a generous and purposive interpretation must be given. ${ }^{42}$ The judges pronounced that article 9 no doubt conferred a 'purposive constitutional protection to the private physical integrity of the person against any form of search' ${ }^{43}$ The Court held: ${ }^{44}$

The protection under section 9(1) would clearly be against any form of undue interference by way of a search of any part of the body of a person without his consent. The coercive taking of fingerprints from the fingers of a person and the extracting of its minutiae would thus clearly fall within the scope of the protection afforded to the integrity and privacy of the person under section 9(1) of the Constitution.

40 Madhewoo case (n 3 above) 20.

41 Madhewoo 21.

42 Olivier v Buttigieg (1967) AC 115; Ong Ah Chuan v Public Prosecutor (1981) AC 648; Attorney-General of The Gambia v Momodou Jobe (1984) AC 689700.

43 Madhewoo case (n 3 above) 21.

44 Madhewoo 22. 
Therefore, it was held that the sections of the 1985 Act and related regulations enforcing the compulsory taking and recording of fingerprints amounted to an interference with the plaintiff's right against the search of his person.

\section{Limitation of the right to privacy of the person}

The Court subsequently considered the exercise of limitation of the right to protection from the search of his body against his will. The judges outrightly qualified the right provided for in section 9 as one that is not absolute and that a limitation to this right was permissible under section 9(2). Indeed, section 9(2) provides that limiting the right to privacy in the interests of public order and for the purposes of protecting rights and freedoms of others is legal and permissible. The Court first considered whether the taking and recording of fingerprints were done 'under the authority of the law'. It relied on authorities from the European Court to interpret the phrase 'under the authority of the law', which is sometimes also termed 'prescribed by the law'. It cited the case of Forderkreis $v$ Germany 45 to explain what should be understood by 'prescribed by the law'. The Court reiterated its settled case law that the expression 'prescribed by law' required firstly that the impugned measure should have a basis in domestic law. It also referred to the quality of the 'law' in question, requiring that it be accessible to the persons concerned and formulated with sufficient precision to enable them - if need be, with appropriate advice - to foresee, to a degree that is reasonable in the circumstances, the consequences which a given action may entail and to regulate their conduct. 46

It was relevant at this point in the judgment for the judges to consider whether the taking and recording of fingerprints were justifiable in the interests of public order. Relying on expert evidence by the project director of the Mauritius National Identity Scheme, Mr Ramah, the Court highlighted the inherent flaws in the previous system with more than 700 cases of applications for the new smart ID card done more than once. Therefore, in the name of national security and the interests of public order, the Court held that, despite the taking and recording of fingerprints being an interference in the enjoyment of the right to privacy, it was something that was necessary in a democratic society. The limitation, therefore, was justifiable. 47

Turning to the issue of storage of personal biometric data including fingerprints, the judges applied the principle of 'reasonably justifiable 
in a democratic society', quoting the following passage from $S$ and Marper $v$ The United Kingdom: ${ }^{48}$

An interference will be considered 'necessary in a democratic society' for a legitimate aim if it answers a 'pressing social need' and, in particular, if it is proportionate to the legitimate aim pursued and if the reasons adduced by the national authorities to justify it are 'relevant and sufficient'.

The retention and storage of fingerprints were held to be meeting a pressing social need and, therefore, amounted to a permissible derogation. However, the Court was not satisfied with the provisions of the 1985 Act and the Data Protection Act related to the security of the retained and stored fingerprints and other biometric information of citizens. Based on expert evidence, the judges concluded that there was too high a risk of unwarranted access to such highly personal data, especially in this era of cybercrime, cyber attacks and hacking.

The Court was of the view that 'the potential for misuse or abuse of the exercise of the powers granted under the law would be significantly disproportionate to the legitimate aim which the defendants have claimed in order to justify the retention and storage of personal data under the Data Protection $\mathrm{Act}^{\prime} .{ }^{49}$ The Court therefore held that the retention and storage of personal data under the Data Protection Act were not reasonably justifiable in a democratic society. The provisions in the 1985 Act and the Data Protection Act allowing for the retention and storage of fingerprints and other biometric information were held to be unconstitutional.

In summary, the Court allowed the taking of fingerprints for the purpose of the new smart ID project. It agreed with the plaintiff that this action amounted to interference with the right to privacy conferred by section 9 . However, it adjudicated that such interference was permissible under the same section based on the interests of public order. As for the retention and storage of fingerprints after having been taken for the smart ID cards, this was held to be unconstitutional as it was not reasonably justifiable in a democratic society.

\section{Insights from the judgment}

\subsection{No constitutional guarantee for a general right to privacy}

The case has shed some much-needed light on the scope of the right to privacy in Mauritius. The Court has made it clear that this particular right encompasses only privacy of the home and property and protection from the bodily search of a person. Other essential components of the right to privacy, such as protection of the private life, family life and correspondence, arguably do not find any 
constitutional guarantee under the Constitution unless, based on facts, a connection can be established with the home, property and body of a person.

It is argued that complete protection of the right to privacy can only be conferred on people when the supreme law of the land provides for the right to privacy and private life. As matters stand, the Mauritian Constitution only seems to provide for a limited right to privacy as interpreted by the Court in the present case. It is reiterated that the Civil Code does provide for the respect of private life, but not to the degree of providing a constitutional guarantee. The Civil Code can easily be amended by a simple majority vote by Parliament while provisions of the Bill of Rights are generally entrenched, thus conferring a higher degree of protection and guarantee to citizens.

\subsection{Judicial activism of the Supreme Court}

In this case, the Supreme Court has unquestionably given a logical decision. The right to privacy or its components is not absolute and is subject to the exercise of limitation of rights under correct conditions. Therefore, the taking of fingerprints for purposes of the ID card amounted to an interference with the privacy of a person, but one which is reasonably justified in a democratic society, whereas the retention and storage of those fingerprints were not. However, what was disturbing in the judgment was the pronouncement by the judges to the effect that there is no general right to privacy in the Bill of Rights. Such a pronouncement makes complete sense, as sections 3 and 9, indeed, literally provide for privacy in relation to the home, property and body of a person.

Nevertheless, the Court's decision that there is no general right to privacy conferred on Mauritian citizens does show a lack of judicial activism on the part of the Court. In any progressive democracy, the role of the judiciary in giving a new dimension to human rights through judicial activism is essential and cannot be ignored. ${ }^{50}$ Black's law dictionary defines judicial activism as a judicial philosophy which motivates judges to depart from their traditional precedents in favour of progress and social policies. ${ }^{51}$ This judicial philosophy has been applied extensively by the Indian Supreme Court, inter alia, in connection with the right to life, to which a new dimension has been given and interpreted to include the variety of rights essential for the enjoyment of the right to life. For instance, it has been held that the right to life includes the right to adequate nutrition, clothing and shelter; ${ }^{52}$ the right to a wholesome environment; ${ }^{53}$ the right to $a$

$50 \mathrm{~N}$ Kamboj 'Human rights and judicial activism' The Indian Law Institute http:// 14.139.60.114:8080/jspui/bitstream/123456789/17749/1/019_Human\%20Righ ts\%20and\%20Judicial\%20Activism\%20(110-115).pdf (accessed 6 January 2017).

51 Law dictionary http://law.academic.ru/12129/judicial_activism (accessed 6 January 2017).

52 Francis Coralie v Union Territory of Delhi AIR 1987 SC 746.

53 MC Mehta $v$ Union of India AIR 1987 SC 1086. 
speedy trial; ${ }^{54}$ the right to free legal aid to the poor; ${ }^{55}$ and the right to know. 56

The Supreme Court of Mauritius has often practised judicial restraint, which is not always suitable for the interpretation and protection of human rights. For instance, the Court had the opportunity to adjudicate that a general right to privacy exists, which can be inferred by reading it into the right to life, as has been done by the Indian Supreme Court. This would not have prevented the judges to eventually find that this right is not absolute and can be reasonably restricted in a democratic society. This would have led to the same decision of allowing the taking of fingerprints for the purposes of ID cards, but not retaining and storing these. At least it would have contributed to establish the right to privacy under the Constitution by way of judicial activism.

It is argued that a certain degree of judicial activism is essential, especially in a jurisdiction such as Mauritius. For instance, the Constitution only provides for civil and political rights, while socioeconomic rights and third generation rights (the rights to development and the environment) are not provided for. It is essential that judges wear the hat of activists and interpret existing rights in a way that would uphold and equally protect second and third generation rights.

\subsection{Reference to the ICCPR}

It is noted that little or no reference has been made to the ICCPR which protects the right to privacy in article 17. Even the plaintiff seemed to have only relied on article 8 of the European Convention on Human Rights. Mauritius is a state party to the ICCPR and has the legal obligation to respect, promote and protect its provisions. Article 17 of the ICCPR clearly provides for the right to privacy and private life which could have supported the argument of the plaintiff. It is trite law that states must endeavour to harmonise its domestic laws, including the Constitution, with international legal standards. With reference to the right to privacy, the ICCPR indeed is a standard that ought to be achieved and matched by the state of Mauritius.

The Court was silent over the fact that the legislature needed to legislate and provide for a more general and effective right to privacy compared to the restricted right currently conferred on Mauritian citizens. The Court also did not consider the fact that, as signatory to the ICCPR, there is a need to harmonise domestic and international law. No doubt, this could have been done while respecting the principle of separation of powers. One may argue that being a dualist state, the ICCPR needs domestication to find application in domestic 
courts. However, it is judicial practice to cite provisions from the ICCPR, especially since it forms part of the International Bill of Rights. In plain words, the ICCPR requires no domestication to find application in the Supreme Court of Mauritius.

\section{Conclusion}

The right to privacy is an essential right which every individual should enjoy. At the same time this right can be limited where necessary in the public interest and for the preservation of public order. The Mauritian Supreme Court carried out the exercise of the limitation of rights in the Madhewoo case. Some of the legislative instruments used for purposes of the new smart ID card were held to have been fairly and legally enacted, while the provisions relating to the retention and storage of fingerprints were held to be unconstitutional. The case has also provided for the status the right to privacy enjoys under the Constitution, with the Supreme Court clearly stating that only privacy in relation to the home, property and body of a person carries a constitutional guarantee.

While the substance of the decision is correct and well founded, the general approach based on judicial restraint diametrically opposed to the principles of implied rights theory, is of real concern. As matters stand, Mauritians only enjoy a segmented right to privacy despite the fact that Mauritius is a state party to the ICCPR. Therefore, there is a need for the Court to draw inspiration from the Indian Supreme Court and other applicable jurisdictions to practise judicial activism where possible in order to be able to imply and infer rights that may not clearly or explicitly be provided for by the Constitution.

In conclusion, the Madhewoo case was correctly decided, but the judgment was based on a surprising ground, namely, that there is no constitutionally-protected right to general privacy and private life in Mauritius. 